\title{
MAPPING FIQH SIYASI: \\ Islamis Versus Sekularis Dan Khilafah Versus Nation States
}

\author{
Moh. Toriquddin
}

UIN Maliki Malang Jl. Gajayana No: 50 Malang, Telp. 085646397073 , email: moh.toriquddin@gmail.com

\begin{abstract}
The current discussions of Fiqh siyasah are still interesting topic to be discussed. These debate using a comparative method such as Islamic politic theories which are "vis to vis"secular and khilafah of vis to vis nation states. Surely, it is hoped, may open the character and unique of Fiqh siyasah itself. Islamic thoughts globally are based on the politic theories such as: religious obligation which was done by Rasulullah Saw. Then, God (Allah) should be the only sovereignty and obey the ruler is necessary as well.Secular thoughts, however, are based on the politic theories such as: ratio. Furthermore, shape of nation can determine anything, the people hold the power, and the president have responsible for people. The system of Islamic politic is a system of khilafah which is exists since the period of Muhammad SAW leaving for Madinah until the downfall of khilafah in Turki. After that, many Moslems Nations gradually adopt democration as their government system.
\end{abstract}

Diskusi tentang persoalan-persoalan figh siyasah terkini masih menjadi topik cukup menarik untuk dibicarakan. Perdebatan dengan menggunakan comparative studi seperti theory politic Islam "visa vis" theory sekuler dan khilafah "vis a vis"sistem kenegaraan. Tentunya, diharapkan dapat membuka karakter dan keunikan dari Figh siyasah itu sendiri.Pemikiran-pemikiran keislaman secara global didasarkan kepada theory politic seperti:kewajiban beragama seperti yangg telah diterapkan oleh Rasulullah Saw. Dimana Tuhan (Allah) harus menjadi satu satunya pemegang kekuasaan dan pemerintah juga harus di taati. Sedangkan pemikiran sekuler lebih berdasar kepada akal. Selain itu, bentuk Negara turut menentukan pemegang kekuasaan, seperti dalam demokrasi warga 
negara memegang kekuasaan dan president bertangggung jawab pada rakyat. Politic Islam adalah sebuah sistem yg telah ada semenjak periode nabi Muhammad SAWsaat menuju madinah sampai dengan saat keruntuhan khilafah di Turki. Sejak saat itu, banyak negara-negara muslim secara bertahap mulai mengadopsi demokrasi sebagai sistem pemerintahan mereka.

Key words: islamic, secolaris, khilafah, nation state

\section{Pendahuluan}

Kata figh secara leksikal berarti tahu, paham dan mengerti.Figh adalah istilah yang dipakai secara khusus di bidang hukum agama, yurisprudensi Islam. Secara etimologis (bahasa) fiqih adalah keterangan tentang pengertian atau paham dari maksud ucapan si pembicara, atau pemahaman yang mendalam terhadap maksud-maksud perkataan dan perbuatan. Secara terminologis (istilah), menurut ulama-ulama syara' (hukum Islam) fiqih adalah pengetahuan mengenai hukum agama Islam yang bersumber dari al Quran dan sunnah yang disusun oleh mujtahid dengan jalan penalaran dan ijtihad. Sedangkan kata siyasat berasal dari kata sasa yang berarti mengatur, mengurus dan memerintah, bisa juga berarti memerintah dan politik, atau membuat kebijaksanaan. Secara terminologis siyasat adalah mengatur atau memimpin sesuatu dengan cara yang membawa kepada kemaslahatan. Selain itu siyasahjuga difahami sebagai ilmu pemerintahan untuk mengendalikan tugas dalam negeri dan luar negeri, yaitu politik dalam dan luar negeri serta kemasyarakatan, yakni mengatur kehidupan umum atas dasar keadilan dan istiqamah (Pulungan, 1999: 21-23).

Selanjutnya figh siyasah,banyak dipakai dengan perluasan pemahaman dan pengertian yang berbeda-beda, seperti zaman Bani Umayyah pemakaian istilah siyasah banyak digunakan untuk sesuatu yang berhubungan dengan militer, dan pada masa ini pula pemahaman siyasah cenderung pada sesuatu perbuatan yang jelek tatkala menjalankan kekuasaan. Dari sinilah muncul kesan bahwa siyasah itu adalah perbuatan kotor.Sedangkan pada masa Abbasiyah pemahaman siyasah diartikan sebagai filsafat politik.Sementara itu ada juga yang memaknainya dengan tindakan yang dapat mengantarkan rakyat lebih dekat kepada kemaslahatan dan lebih jauh dari kerusakan, kendati Rasulullah tidak menetapkan dan Allah juga tidak menurunkan wahyu untuk mengaturnya, yang jelas siyasah itu lebih banyak mengutamakan kepentingan rakyat (Syarif, dkk, 2008: 6-8).

Pada tulisan ini pembahasan akan difokuskan pada fiqih siyasah: Islamis versus sekularis dan khilafah versus nation states. Dengan harapan, agar bisa 
mengetahui karakteristik dan keunikan dari masing-masing aliran fiqih siyasah tersebut.

\section{Teori Politik Islamis}

Setelah melakukan pembacaan terhadap karakteristik pemikiran politik Islamis maka, teori politik Islamis terbagi menjadi dua bagian yaitu Islamis ortodok dan Islamis modern (al Maududi,2010: 11). Islamis ortodok lebih bersifat kaku dengan berusaha menerapkan pengalaman yang pernah dilakukan pada zaman Nabi SAW untuk diterapkan di zaman sekarang. Sedangkan Islamis modern di samping secara subtansial masih berpegang pada syariat Islam (al Quran dan Sunnah), ia juga mengadopsi teori politik barat.

\section{Islamis Ortodok}

Menurut al Maududi (1930-1974M) iman terhadap keesaan dan kekuasaan Allah merupakan landasan sistem sosial dan moral dan sekaligus sebagai pijakan filsafat politik Islam.Prinsip dasar Islam adalah bahwa makhluk manusia, baik secara individual maupun kelompok, harus menyerahkan semua hak atas kekuasaan, legislasi serta penguasaan atas sesamanya.Tidak seorangpun diperkenankan memberikan perintah atau aturan-aturan sekehendaknya sendiri dan tidak seorangpun diperkenankan untuk mengakui kewajiban untuk melaksanakan perintah atau aturan seperti ini. Tidak seorangpun diberi hak istimewa untuk membuat undang-undang sekehendak hatinya dan tidak seorangpun wajib mengikatkan dirinya kepada undang-undang yang telah dibentuk dengan cara seperti ini. Hak ini hanya merupakan hak Allah (al Maududi, 1995: 154):

Kewenangan hanyalah milik Allah.Ia memerintahkan agar kamu hanya menyembah kepada-Nya. Itulah agama yang benar. (QS Yusuf: 40).

Mereka bertanya: apakah kami juga memiliki beberapa kewenangan? Katakanlah: semua kewenangan hanya milik Tuhan semata (QS Ali Imran: 154)

Janganlah mulutmu lancang dengan mengatakan secara dusta: yang ini halal yang ini haram (QS an Nahl: 116)

Barang siapa yang menegakkan dan memutuskan suatu masalah tidak berdasarkan apa yang telah diwahyukan Allah, maka mereka ini termasuk ke dalam orang-orang kafir (QS al Maidah: 44).

Tampaknya pemikiran al Maududi ini dilatarbelakangi kekecewaannya terhadap runtuhnya khilafah pada tahun 1924 yang mengakibatkannya menjadi sinis terhadap nasionalisme yang ia yakini hanya menyesatkan orang Turki dan Mesir, dan menyebabkan mereka merongrong kesatuan 
muslim dengan cara menolak imperium 'Utsmaniah dan kekhalifahan (al Maududi, 2010: 11).

Menurut teori ini, kedaulatan ada di tangan Allah.Dia sendirilah yang merupakan pemberi hukum. Tidak seorangpun, sekalipun rasul, yang berhak memerintah orang lain sekehendak hatinya sendiri untuk melakukan atau tidak melakukan sesuatu. Rasul sendiri merupakan subyek dari perintah-perintah Tuhan, sesuai dengan firman-Nya: Katakanlah: aku hanya mengikuti apa yang telah diwahyukan kepadaku(QS al An'am: 50).

Sedangkan orang lainnya dituntut untuk mematuhi perintah Rasul karena dia tidak mencanangkan perintahnya sendiri melainkan perintahperintah Tuhan: Tidaklah kami utus Rasul itu kecuali untuk ditaati dengan seizin Allah (QS an Nisa': 64).

Dengan demikian karakteristik utama suatu negara Islam yang dapat digali dari pernyataan-pernyataan kitab suci al Quran adalah sebagai berikut: (1) tuhan adalah pemilik kedaulatan mutlak, (2) hak pemberi hukum hanyalah ada pada Tuhan, (3) suatu negara Islam dalam segala hal harus didasarkan pada hukum yang telah diturunkan Allah kepada manusia melalui Rasulullah SAW.

Filsafat politik Islam merupakan antithesis dari demokrasi Barat.Landasan filosofis demokrasi Barat adalah kedaulatan rakyat. Yang mana penentuan nilainilai dan norma perilaku berada di tangan rakyat. Jika sebagian legislasi khusus diinginkan massa, betapapun jahatnya ditinjau dari segi moral keagamaan, maka legislasi itu harus dimasukkan ke dalam kitab undang-undang, atau sebaliknya maka ia harus dilenyapkan dari kitab undang-undang. Hal ini sangat bertentangan dengan Islam, Islam hanya menyandarkan kedaulatan sepenuhnya pada Tuhan (al Maududi, 1995: 156-159).

Al Maududi menguraikan lebih lanjut bahwa negara Islam bersifat universal dan menyeluruh serta bercirikan negara ideologis. Negara ini berusaha meramu setiap sektor kehidupan dan kegiatan masyarakat sejalan dengan norma-norma moralnya dan program reformasi sosialnya.Negara ideologis artinya negara ini berlandaskan suatu ideologi dan bertujuan untuk menegakkan ideologi tersebut.Islam tidak mengakui sepenuhnya perbedaan geografis, bahasa maupun warna kulit.Islam mengetengahkan aturan-aturan tuntunannya serta rancangan reformasinya kepada semua manusia.Siapa pun yang mengakui program ini tanpa mempedulikan rasnya, bangsa maupun negaranya dapat bergabung dengan masyarakat yang menyelenggarakan negara Islam.Mereka dapat tinggal dalam batas-batas negara itu sebagai warga 
negara non Muslim. Hak-hak khusus telah diberikan kepada mereka dalam hukum Islam. Kehidupan minoritas ini, kekayaan dan kehormatannyaakan sepenuhnya dilindungi (al Maududi,1995: 166-167).

Dalam surat (an Nur: 55) disebutkan:

Allah telah menjanjikan kepada orang-orang yang beriman dan mengerjakan kebajikan, bahwa Dia akan memberikan kekhalifahan kepada mereka di belahan bumi ini, sebagai mana Dia telah memberikan kekhalifahan kepada umat sebelumnya.

Ayat ini menguraikan secara jelas teori Islam mengenai negara. Dari sini ada dua masalah mendasar yang mencuat yaitu:

a. Islam menggunakan istilah kekhalifahan, bukan kedaulatan. Karena menurut Islam kedaulatan hanya milik Allah. Siapapun yang memegang tampuk kekuasaan dan memerintah sesuai dengan hukum Tuhan adalah khalifah dari penguasa tertinggi dan tidak akan berwenang mengerahkan kekuasaan apapun kecuali kekuasaan-kekuasaan yang telah didelegasikan kepadanya.

b. Kekuasaan untuk memerintah bumi telah dijanjikan kepada masyarakat Mukmin. Semua kaum beriman merupakan penjelmaan dari kekhalifahan sesuai dengan kemampuan individunya.Dengan demikian dia secara individual bertanggung jawab kepada Tuhan (al Maududi, 1995: 169).

Khalifah secara teoritis bisa dipilih atau dicalonkan oleh sekelompok pemimpin masyarakat, tepatnya "ulama" yang berpengaruh (ahl al hal wa al 'aqd); tetapi hal ini jarang sekali terjadi.Selain itu khalifah juga bisa ditunjuk oleh pendahulunya (khalifah yang berwenang); dan inilah yang biasa berlaku. Di sini sebenarnya al Maududi memaklumi bahwa sejarah pemilihan khalifah dalam Islam hampir tidak pernah terjadi kecuali di masa khulafaurrasyidin, yang ada hanyalah penunjukan secara langsung yang pada prinsipnya telah mementahkan teorinya sendiri. Pemilihan atau penunjukan seorang khalifah dilanjutkan dengan penerimaan komunitas atau pengakuan publik (bay'ah). Idealisme moral dari teori politik kekhalifahan terutama jelas dalam kualifikasi resmi bagi khalifah yaitu: adil, pengetahuan untuk menafsirkan dan menerapkan hukum ilahiyah (syariah), karakter yang baik, keberanian untuk ikut dalam peperangan, kesehatan fisik yang baik, dan yang terakhir keturunan kaum quraisy (Azra, 1996: 5).

Al Maududi juga menjelaskan masalah perang. Dalam hal ini sebenarnya disebabkan terbunuhnya Swami Shradhnand pemimpin kebangkitan Hindu oleh seorang muslim pada 1925,yang mengakibatkan citra Islam buruk di 
mata orang Pakistan (al Maududi, 2010: 11). Peperangan dimaksudkan sebagai suatu cara untuk menghentikan pertentangan serta melindungi tatanan moral yang terancam dengan adanya hasutan dari kaum kafir. Tapi perjuangan suci ini juga mengenal batas-batas yang ditetapkan Allah dan Rasul-Nya. Kaum muslim dilarang melampaui batas tersebut antara lain dengan pelarangan menyatakan perang lebih dahulu, larangan melakukan perusakan, menghindari penghancuran harta milik orang sipil, membunuh orang yang tidak terlibat dalam perang, atau membunuh musuh yang telah menyatakan memeluk Islam di medan perang (Azra, 1996: 156).

Dari uraian di atas sangat jelas bahwa al Maududi menginginkan negara Islam Madinah muncul kembali pada konsep politiknya.Hal ini sangat kecil kemungkinan untuk terealisasi walaupun bukan mustahil, mengingat kemajemukan negara Islam kontemporer dan masing-masing negara sarat dengan kepentingan-kepentingan terhadap negara Barat khususnya Amerika.

\section{Islamis Modern}

Menurut Jamaluddin al Afghani (1839-1897 M) Islam menghendaki bentuk Republik. Sebab di dalamnya terdapat kebebasan berpendapat dan kepala negara harus tunduk kepada undang-undang dasar.Pendapat ini baru dalam sejarah politik Islam, sebab sebelumnya dan sampai di masa Afghani umat Islam dan pemikirnya hanya mengenal bentuk khilafah yang mempunyai bentuk kekuasaan absolut. Sedangkan negara yang berpemerintahan republik, yang berkuasa adalah undang-undang dan hukum, bukan kepala negara.Ia hanya punya kekuasaan untuk menjalankan undang-undang dan hukum yang digariskan oleh lembaga legislatif untuk memajukan kemaslahatan rakyat. Bukti keinginan Afghani akan pemerintahan yang demokratis adalah penegasannya tentang keharusan Kepala negara mengadakan syura dengan pemimpinpemimpin masyarakat yang banyak pengalaman. Syura diperintahkan oleh Allah dalam al Quran agar dipraktekkan dalam berbagai urusan (Pulungan, 1999: 281-285).

Pendapat Afghani kelihatannya merupakan sintesa dari pemahamannya terhadap ajaran yang menekankan pentingnya melaksanakan musyawarah, dan pengamatannya terhadap pemerintahan otokrasi pada zamannya yang tercermin dalam pemerintahan khilafah. Karenannya ia berpendapat pemerintahan otokrasi yang cenderung meniadakan hak-hak individu tidak sesuai dengan ajaran Islam yang sangat menghargai hak-hak individu. Maka pemerintahan otokrasi harus diganti dengan pemerintahan yang bercorak demokrasi yang 
menjunjung tinggi hak-hak individu (Pulungan, 1999: 286).

Konsep pan-Islam-nya al Afghani rupanya tidak direstui oleh penguasa kerajaan. Dia menghendaki agar masyarakat Muslim menentukan nasib mereka sendiri dengan jalan bersatu-padu dan mendesak penguasa untuk memerintah sesuai kepentingan rakyat dan melindungi mereka dari kekuatan asing yang tamak dan serakah.Karena itu dia menentang keras para penguasa yang hanya memperhatikan kekuasaan dan hak istimewa mereka tanpa memperdulikan kesejahteraan rakyat.Dia menyarankan agar mereka menciptakan dunia Islam sebagaimana yang seharusnya (Engineer, 2000: 149).

Afgani juga memompa semangat kaum Muslim dengan jalan membangkitkan kenangan masa silam yang gilang-gemilang, yang menjadi misi utamanya adalah membangunkan kaum Muslim dari tidur nyenyak mereka.Dia juga berpikir keras untuk menguras habis unsur-unsur feodal dari Islam dan menggantinya dengan nilai-nilai keilmuan modern. Namun Afghani juga memperlihatkan apresiasi yang berat sebelah terhadap nilai-nilai intelektualisme Barat, terutama bidang ipteknya.Secara umum dia memandang Barat sebagai sesuatu yang harus dicegah karena dapat membahayakan Islam dan masyarakat, namun ada pula yang perlu ditiru. Dia sangat getol menganjurkan kepada khalayak muslim untuk mengembangkan iptek sebagaimana yang dilakukan oleh Barat, dalam upaya memperkuat diri (Engineer, 2000:153).

Afgani tampak ambifalen, di satu sisi ia menginginkan nilai-nilai keislaman tetap dihidupkan dalam konsep politiknya, seperti musyawarah dalam menentukan berbagai urusan negara. Namun di sisi lain ia menginginkan bentuk pemerintahan republik yang menurutnya akan lebih membawa kepada keadilan. Padahal pemerintahan republik adalah murni produk Barat. Hal ini terjadi tidak lain karena ia tidak rela melihat kedzaliman yang dilakukan oleh para khalifah, akan tetapi ia belum mempunyai alternatif lain untuk memuluskan idenya selain menengok ke dunia Barat termasuk juga soal iptek.

Sedangkan Muhammad Abduh (1849-1905 M) kelahiran Mesir adalah murid Afghani yang setia. Dalam pandangan Abduh, Islam tidak menetapkan suatu bentuk pemerintahan. Jika sistem khilafah masih tetap menjadi pilihan sebagai model pemerintahan, maka bentuk demikian pun harus mengikuti perkembangan masyarakat dalam kehidupan materi dan kebebasan berpikir. Abduh melihat sikap jumud merupakan penyebab kemunduran umat Islam, akibat dari pemerintahan sewenang-wenang, absolut. Juga tidak terlepas dari pengertian Islam yang dipahaminya. Syariat menurutnya mempunyai pengertian sempit dan luas. Syariat dalam pengertian sempit adalah himpunan hukum- 
hukum Allah dan Rasul-Nya, yaitu pokok-pokok ajaran Islam yang tidak berkembang dan tidak berubah, sedangkan syariat dalam pengertian luas adalah kaidah-kaidah yang mengatur kehidupan kaum muslimin yang dapat disamakan dengan al tasyri' al Islam (perundamg-undangan Islam) (Pulungan, 1999: 282).

Perundang-undangan yang dihasilkan oleh ijtihad melalui penafsiran dasar-dasar agama secara rasional di bidang muamalah yang selalu berkembang untuk memelihara kemaslahatam masyarakat. Selanjutnya ia menegaskan bahwa sumber kedaulatan bagi pemerintah dalam Islam adalah rakyat. Rakyatlah yang mempunyai kekuasaan untuk mengangkat dan memaksa pemerintah. Karenanya rakyat harus menjadi pertimbangan utama dalam menetapkan hukum untuk kemaslahatan mereka (Pulungan, 1999: 287).

Abduh lebih moderat dari pada gurunya, Afgani. Hal ini terlihat dalam pandangannya bahwa bentuk pemerintahan boleh berupa apa saja asalkan dengan syarat harus mengikuti perkembangan zaman. Ia mencoba memberikan solusi agar hukum Islam sesuai dengan zaman dan tempat dengan pandangannya bahwa syari'at mempunyai dua pengertian yaitu sempit dan luas, yang dari sudut pandang yang luas inilah hukum Islam akan selalu bisa beradaptasi dengan kemajuan dan kedaulatan tertinggi adalah di tangan rakyat.

Sementara al Qardlawi mengatakan yang paling dibutuhkan untuk da'wah Islam di zaman sekarang ini adalah, mendirikan Dar al Islam atau negara Islam yang mengadopsi risalah Islam baik akidah dan undang-undang, ibadah dan akhlak, cara hidup dan kebudayaan yang bisa menjalankan kehidupan baik secara materi dan adab dengan berdasar pada risalah yang lengkap serta menerima setiap orang Islam yang ingin hijrah ke negara tadi dari Dar al Kufr dan dzalim serta yang menyeleweng.

Negara yang dirindukan ini merupakan kebutuhan secara Islam dan kemanusiaan. Hal ini akan memajukan manusia pada hidup yang ideal karena menyatunya agama dan dunia. Serta bercampurnya materi dengan ruh. Keserasian antara peradaban yang tinggi dengan akhlak yang luhur, akhlak merupakan batu pertama untuk mendirikan negara Islam yang besar, yang menyatukan umat Islam di bawah bendera al Quran dan dalam naungan pemerintahan Islam (al Qardhawi, 1999: 21).

Negara Islam bukan Kerajaan dan Kekaisaran yang berdiri berdasarkan warisan serta menyerahkan kendali hukum pada satu keluarga atau kelompok keluarga yang perpindahan kekuasaanya secara waris dari seorang bapak ke anaknya, kakek ke cucunya seperti diwarisnya bangunan dan harta, walaupun 
mereka orang yang paling bodoh akalnya serta paling rusak akhlaknya. Negara Islam berdiri di atas dasar-dasar demokrasi, tetapi bukanlah negara demokrasi Barat.Ia sesuai dengan demokrasi Barat pada masalah pemilihan pemimpin dan pada masalah tanggung jawab seorang pemimpin di depan dewan, musyawarah dan pengambil kebijakan, hingga mereka mempunyai hak untuk memecat pemimpin ketika dia menyeleweng dan tidak mau mendengarkan nasehat. Lebih dari itu Islam menjadikan tiap individu baik laki-laki maupun perempuan berhak menasehati pimpinan dan amar ma'ruf nahi munkar sebagai hak seorang mukmin terhadap mukmin lainnya tidak memandang jabatan dan kedudukannya.

Demokrasi Barat walaupun mempunyai sisi positif namun tidak ada dasar hukum yang mengikat, tidak ada nilai-nilai yang memantau perjalanan hukum. Maka dengan mengatas namakan wakil rakyat mereka mampu menggagalkan keutamaan dan menetapkan kenistaan serta membuat undang-undang yang dzalim, menghalalkan yang haram dan mengharamkan yang halal. Dari sini syura yang ada pada negara Islam berbeda dengan yang ada pada negara demokrasi. Syura merupakan batasan yang tidak bisa dilewati. Akidah Islam yang bersifat keimanan dan rukun-rukun yang bersifat perbuatan, dasar-dasar akhlak dan hukum-hukum yang pasti. Itu semua merupakan nilai dasar yang diridhai masyarakat dan berdiri di atasnya undang-undang hidup yang tidak ada ruang untuk musyawarah, baik parlemen maupun pemerintah tidak berhak untuk menghapus sesuatupun darinya. Karena apa yang telah di tetapkan oleh Allah tidak bisa di hilangkan oleh manusia. Pemilih di mata Islam adalah sebagai saksi, maka syarat pemilih sama seperti syarat yang ada pada saksi yaitu, adil dan baik tingkah lakunya (al Qardhawi, 1999: 35-36).

Berbeda dengan Abduh al Qardlawi terang-terangan menerima demokrasi namun ia menegaskan demokrasi yang ia maksudkan adalah demokrasi versi Islam. Demokrasi dari hasil penafsiran kata syura dalam al Quran.Ia juga memberikan hak-hak rakyat untuk amar ma'ruf nahi munkar dengan mengingatkan pemimpin mereka yang dzalim serta menempatkan pemilih sebagai saksi di dalam Islam.

\section{Teori Politik Sekularis}

Dalam teori politik sekularis juga terbagi menjadi dua yaitu sekular Islam dan sekular Barat. Sekular Islam masih mempertimbangkan pemberlakuan syariat walaupun syariat itu lepas sama sekali dari kontrol negara, sedangkan sekular Barat tidak mempertimbangkan pemberlakuan syariat sama sekali. 
Dengan kata lain sekular Barat mempunyai prinsip walaupun suatu keputusan hukum bertentangan dengan syariat asalkan disetujui oleh mayoritas pengambil kebijakan negara, maka hukum itu dianggap sah.

1. Sekular Islam

Menurut Ali Abdul Raziq (1888-1966 M) khilafah adalah satu pola pemerintahan di mana kekuasaan tertinggi dan mutlak berada pada seorang Kepala negara/pemerintah dengan gelar khalifah, pengganti Nabi besar Muhammad SAW dengan kewenangan untuk mengatur kehidupan dan urusan umat/rakyat, baik keagamaan atau keduniaan, yang hukumnya wajib bagi umat untuk patuh dan taat sepenuhnya. Mendirikan khilafah bukan merupakan kewajiban agama.Menurutnya memang benar dalam hidup bermasyarakat tiap kelompok manusia memerlukan penguasa yang mengatur dan melindungi kehidupan mereka, terlepas dari agama dan keyakinan mereka, apakah Islam, Nasrani, Yahudi atau penganut agama lain, dan bahkan mereka yang tidak beragama sekalipun (Sjadzali, 1993: 140). Penguasa itulah pemerintah. Tetapi pemerintah itu tidak harus berbentuk khilafah melainkan dapat beraneka ragam bentuk dan sifatnya, apakah konstitusional, atau kekuasaan mutlak, apakah Republik atau diktator dan sebagainya. Inti paham politik Raziq adalah statemennya yang menyatakan bahwa Nabi Muhammad SAW adalah sematamata seorang utusan Allah untuk mendakwahkan agama murni tanpa maksud untuk mendirikan negara. Nabi tidak mempunyai kekuasaan duniawi, negara ataupun pemerintahan. Nabi tidak mendirikan kerajaan dalam arti politik atau sesuatu yang mirip dengan kerajaan. Dia adalah Nabi sama seperti halnya para Nabi sebelumnya. Dia bukan raja, bukan pendiri Negara dan tidak pula mengajak umat untuk mendirikan kerajaan duniawi (Sjadzali, 1993: 143).

Raziq beranggapan bahwa mendirikan negara bukan merupakan kewajiban agama, dan apapun bentuk negara adalah sah sah saja.Bahkan lebih tegas lagi menurutnya nabi diutus hanya untuk menyampaikan risalah bukan untuk mendirikan negara, apapun bentuk negara itu. MenurutAbidal Jabiri dalam Islam tidak ada teks yang menentukan jenis pemerintahan yang harus diikuti oleh kaum Muslim, tidak ada teks pula yang melarang mereka untuk mengikuti jenis pemerintahan tertentu. Inilah yang menjadi alasan bagi tokoh-tokoh berbagai aliran dalam Islam yang berpendapat bagi kemungkinan tidak mutlaknya kepentingan adanya khalifah yang juga berakibat pada tidak perlunya sebuah negara jika masing-masing kaum muslim dapat menegakkan perintah dan larangan agama; satu hal yang membuat kebutuhan akan seorang penguasa itu menjadi gugur (al Jabiri, 2001: 70). 
Lebih jauh al Jabiri berpendapat bahwa terjadinya peristiwa "kekacauan besar"(al Fitnah al kubra), yakni berbagai peristiwa di tahun-tahun terakhir pemerintahan Ustman adalah merupakan ekspresi dari kekosongan perundangundangan dalam system pemerintahan yang didirikan setelah Nabi Muhammad SAW wafat. Ia memerinci kekosongan itu dalam tiga masalah: pertama, tidak adanya penentuan metode tertentu yang diundangkan dalam memilih khilafah. Kedua,tidak adanya batasan bagi masa jabatan khalifah.Ketiga,tidak adanya pembatasan bagi wewenang seorang khalifah. Al Jabiri juga mengajak untuk memisahkan antara agama dengan negara; bahkan menjadikannya sebagai syarat kemajuan dan kebangkitan, ia meletakkan batas pemisah antara agama dan peradaban; keharusan membuat pemisah antara kekuasaan ruhani dan kekuasaan peradaban, atau dengan ungkapan yang masyhur, "berikan kepada Tuhan apa yang menjadi hak Tuhan, dan berikan kepada Kaisar apa yang menjadi hak Kaisar (al Jabiri, 2001: 92).

Al Jabiri menafikan adanya perintah mendirikan negara dan model Negara dalam Islam, bahkan menurutnya selama umat Islam bisa menjalankan aktivitas keagamaannya maka mendirikan negara bukan merupakan keharusan. Selanjutnya ia terang terangan mengajak untuk memisahkan antara agama dan negara dan menjadikannya prasyarat untuk kemajuan. Menurut Muhammad Husain Haikal bahwa kehidupan bernegara bagi umat Islam itu baru mulai pada waktu Nabi berhijrah dan menetap di Madinah, dan di tempat yang baru itulah Nabi berdasarkan wahyu-wahyu ilahi mulai meletakkan ketentuanketentuan dasar bagi kehidupan keluarga, pembagian waris, usaha dan jual beli. Sedangkan ayat-ayat yang diwahyukan dalam periode Mekkah terbatas pada ajaran untuk mengesakan Tuhan dan iman atau percaya kepada Allah, para malaikat dan Rasul Allah, hari akhir, serta nilai-nilai kemanusiaan yang tinggi. Bahkan ketentuan-ketentuan dasar tentang kehidupan bermasyarakat, kehidupan ekonomi, dan budi pekerti tersebut belum menyentuh secara rinci dasar-dasar bagi kehidupan bernegara (Sjadzali, 1993:183).

Masih menurut Haikal, di dalam Islam tidak terdapat satu sistem pemerintahan yang baku. Umat Islam bebas menganut system pemerintahan yang bagaimanapun asalkan system tersebut menjamin persamaan antara para warga negaranya, baik hak maupun kewajiban, dan juga di muka hukum, dan pengelolaan urusan negara diselenggarakan atas musyawarah, dengan berpegang kepada tata nilai moral dan etika yang diajarkan Islam bagi peradaban manusia. Lebih lanjut menurutnya, sistem pemerintahan yang sesuai dengan ketentuan-ketentuan Islam adalah sistem yang menjamin kebebasan dan 
berasaskan prinsip bahwa pengangkatan Kepala negara dan kebijaksaannya harus dengan persetujuan rakyat, bahwa rakyat berhak mengawasi pelaksanaan pemerintahan dan meminta pertanggungjawaban (Sjadzali, 1993: 189).

Pandangan al Jabiri tidak jauh dengan Haikal yang menyatakan bahwa Islam tidak mempunyai sistem pemerintahan yang baku dan bagaimanapun bentuk suatu negara tidak menjadi masalah selama hak masyarakat di mata hukum semuanya sama, hanya saja Haikal tidak mengajak untuk memisahkan antara negara dengan agama. An Na'im berpendapat bahwa prinsip-prinsip atau aturan syari'ah tidak dapat diberlakukan dan diterapkan secara formal oleh negara sebagai hukum dan kebijakan publik hanya karena alasan bahwa prinsip-prinsip dan aturan-aturan itu merupakan bagian dari syari'ah. Apabila pemberlakuan syari'ah seperti itu diusahakan, hal itu merupakan kehendak politik negara dan bukan hukum Islam. Adanya klaim elit penguasa yang kadang melegitimasi kekuasaan negara atas nama syari'ah tidak lantas berarti bahwa klaim itu benar atau mungkin dilaksanakan. Mengingat prinsipprinsip syari'ah ditinjau dari watak dan fungsinya memang menolak setiap kemungkinan penerapan syari'ah oleh negara, klaim untuk melakukan hal itu bertentangan dengan logika, sekalipun berbagai upaya dilakukan untuk mengatasi pertentangan itu. Dengan kata lain masalahnya bukan sekadar karena kurangnya pengalaman sehingga dapat ditingkatkan di sana-sini, tapi tujuan yang ingin dicapai memang mustahil untuk diraih. Namun demikian anNa'im tidak mengatakan bahwa Islam harus dikeluarkan dari perumusan kebijakan publik dan perundang-undangan atau dari kehidupan publik pada umumnya. Sebaliknya negara tidak perlu berusaha menerapkan syari'ah secara formal agar umat Islam benar-benar dapat menjalankan keyakinan Islamnya secara sungguh-sungguh, sebagai bagian dari kewajiban beragama bukan karena paksaan negara (an Na'im, 2007:16).

Menurut an Na'im, netralitas agama hanya bisa dilakukan dengan dua hal; Pertama, negara territorial modern seharusnya tidak mencoba menjalankan syariah sebagai hukum positif dan kebijakan publik, juga tidak mengklaim penafsiran doktrin-doktrin dan prinsip-prinsipnya bagi warga negara Muslim. Kedua, prinsip-prinsip syariah dapat dan seharusnya menjadi sumber kebijakan dan perundang-undangan publik serta tunduk kepada hak-hak konstitusional dan hak-hak asasi manusia bagi seluruh warga negara, laki-laki dan perempuan Muslim dan non Muslim tanpa diskriminasi. Dengan kata lain, prinsip-prinsip syariah tidak bisa menjadi hak istimewa atau dipaksakan begitu saja, tidak juga ditolak sebagai sumber hukum dan kebijakan negara. Keyakinan sebagian besar 
warga negara sekalipun bahwa prinsip-prinsip syariah merupakan kewajiban agama yang mengikat harus tetap menjadi asas bagi pelaksanaan ibadah kolektif dan individual di kalangan para penganut, tetapi tidak bisa digunakan begitu saja sebagai dasar bagi pelaksanaannya oleh negara (an Naim, 2007: 58).

Lebih jauh an Na'im menekankan bahwa kedaulatan sepenuhnya berada di tangan rakyat yang dalam hal ini ia sebut dengan "public reason" (nalar publik). Yang ia maksudkan dengan "nalar publik" adalah bahwa alasan, maksud, dan tujuan kebijakan publik atau perundang-undangan harus didasarkan pada pemikiran yang di dalamnya warga pada umumnya bisa menerima atau menolak, dan membuat usulan tandingan melalui debat publik tanpa ketakutan dituduh kafir atau murtad. Nalar dan penalaran publik, dan bukan keyakinan dan motivasi personal, mutlak adanya bagi kaum muslim, baik sebagai penduduk mayoritas ataupun minoritas, karena sekalipun muslim sebagai mayoritas mereka tidak lantas bersepakat terhadap kebijakan dan perundang-undangan mana, yang serta merta cocok dengan keyakinan Islam mereka (an Na'im, 2007: 22-23). Menurut an Na'im, Syariah akan kehilangan otoritas dan nilai agamanya bila diterapkan melalui negara. Ia menekankan perlunya menjaga netralitas negara terhadap agama dan pemisahan secara kelembagaan antara Islam dan negara. Agar syariah bisa berperan positif dan mencerahkan bagi kehidupan umat dan masyarakatIslam. An Na'im selanjutnya menegaskan relativitas syariah, karena ia merupakan produk pikiran manusia terhadap al Quran dan sunnah oleh karena itu, ia tidak bisa terlepas dari pengaruh ruang dan waktu, konteks historis, sosial, dan politik penafsirnya. Syariah dengan demikian tidak suci, apalagi kekal dan permanen yang bisa berlaku untuk semua waktu dan tempat (http://zfikri.wordpress.com/2007/08/11/ kritik-kpd-an-naim-shariah-yes-ham-no. diakses tgl 25-6-2010).

\section{Teori Khilafah Versus Nation States}

Imamah juga disebut khilafah sebab, orang yang menjadi khalifah adalah penguasa tertinggi bagi umat Islam yang menggantikan Nabi Muhammad SAW. Khalifah itu juga disebut imam sebab para khalifah adalah pemimpin (imam) yang wajib ditaati.Manusia berjalan di belakangnya, sebagaimana manusia shalat di belakang imam (as Salus, 1997: 16). Sebuah teori politik yang cukup artikulatif dari kalangan ahli Sunnah pada akhirnya muncul di pertengahan pertama abad ke-11.Doktrinnya mengenai kekhalifahan memuaskan dahaga komunitas agama yang sedang galau karena menurunnya harapan mereka secara drastis kepada lembaga kekhalifahan, seraya tetap memelihara legitimasi 
Abbasiyah sebagai pemimpin umat Islam.Empat khalifah pertama (Khulafa' al Rasyidin) kini mendapatkan sebuah kategori khusus. Dorongan utama teori ini adalah melindungi kekhalifahan Abbasiyah dari alternatif-alternatif lain Syi'ah Imamiyah atau Syi'ah Ismailiyah, khususnya dari keluarga Fatimiyah yang mungkin tampil sebagai pemimpin sah di mata rakyat muslim.

Keharusan tunduk pada khalifah atau imam ditegaskan oleh Ibnu Hambal kecuali jika ia murtad atau tidak menyelenggarakan shalat jum'at. Kalau tidak, bahkan seorang perebut kekuasaan pun, bila ia berhasil menjalankan kekuasaannya, harus dipatuhi. Al Asyari sendiri mencela orang yang menganggap benar tindakan melawan imam ketika ia menunjukkan tanda-tanda penyimpangan dari kebenaran, (Kami) menolak pemberontakan bersenjata menentang (Khalifah yang sedang berkuasa) dan kami menolak perang saudara. Politik tanpa perlawanan (non resistensi) menjadi sikap yang secara luas diamini oleh kalangan sunni. Seorang pengikut Hambali, misalnya mengajarkan bahwa pemberontakan politik hanya akan mengacaukan persatuan umat Islam, tidak sepatutnya menentang pemimpin, kecuali ia memerintah untuk mengingkari Tuhan, maksudnya adalah pelanggaran terhadap syari'at secara terang-terangan, dan tentunya penguasa yang berpikiran waras tidak akan melakukan tindakan bodoh semacam itu (Black, 2001: 166-168).

Secara normatif, khilafah sesungguhnya adalah ajaran milik umat Islam. Ketentuan normatif itulah yang diamalkan secara nyata oleh umat Islam dalam sejarah panjang mereka, sejak berdirinya daulah Islamiyah tahun $622 \mathrm{M}$ tatkala Rasulullah berhijrah ke Madinah hingga runtuhnya khilafah di Turki Tahun 1924 (Syarif, Dkk., 2008: 215). Sekarang, selain sistem pemerintahan khilafah, ada sistem pemerintahan lain yang dipraktekkan oleh umat Islam di sejumlah negara-negara muslim, bahwa nation states (negara bangsa) itu adalah sistem pemerintahan demokrasi. Kata demokrasi memiliki berbagai makna.Tetapi sekarang ini penggunaannya mengandung arti bahwa kekuasaan tertinggi di dalam urusan-urusan politik adalah hak rakyat. Demokrasi adalah suatu bentuk pemerintahan dimana keputusan-keputusan penting pemerintah atau garis kebijaksanaan di belakang keputusan-keputusan tersebut secara langsung atau tidak langsung hanya dapat diakui jika disetujui oleh mayoritas rakyat. Beberapa negara yang mayoritas penduduknya muslim menganut sistem demokrasi dalam menjalankan pemerintahan. Namun demokrasi, yang pengaruh Islam dalam pemerintahan masih begitu nampak dan banyak perundang-undangan yang berbasis pada syari'at. Demokrasi tidak dijalankan secara sekuler seperti negara-negara Barat, melainkan demokrasi yang mendapat pengaruh Islam 
(Syarif, Dkk., 2008: 216). Selain agama, pilihan lain untuk menjadi dasar identitas kewarganegaraan secara umum, terutama di eropa, adalah identitas kebangsaan. Kaum muslim sejak dulu mengakui nilai kebangsaan; bangsa dari berbagai ras, warna kulit, bahasa, dan adat-istiadat hidup dalam komunitas agama yang sangat luas. Tetapi hingga akhir abad ke-19, kebangsaan tidak pernah dipandang sebagai sebuah dasar untuk kenegaraan (kendati Iran secara de facto adalah negara-bangsa, Syi'ah tetap menjadi identitas kewarganegaraan).

Ide tentang negara-bangsa memasuki pemikiran politik Islam seiring dengan masuknya ide-ide politik Eropa lainnya. Cinta tanah air atau Negara (wathan:patrie) mulai dipropagandakan oleh beberapa penulis Mesir dan Turki sebagai sebuah kebajikan. Tahtawi (1801-1873 M) berpendapat bahwa seseorang dari tanah air yang sama mempunyai kewajiban yang sama satu sama lain, layaknya hubungan satu orang dengan orang lain dalam satu agama yang sama (Black, 2001: 620). Lutfi al Sayyid (1872-1963, juga seorang Mesir) mengaitkan universalisme (pemikiran bahwa "tanah Islam adalah tanah air seluruh muslim") dengan imperialism Islam (yakni Utsmani/Turki). Menurutnya gagasan itu sudah usang dan harus digantikan "dengan satu kepercayaan yang sesuai dengan ambisi setiap negara Timur yang mempunyai tanah air tertentu yaitu rasa nasionalisme (wathaniyah) (Black, 2001: 620).

Tabel 1. Pemetaan Fiqh SiyasahIslamis Vs Sekularis

\begin{tabular}{|l|l|l|l|}
\hline No & Aliran Politik & Tokoh & Karakter Pemikiran \\
\hline 1. & Islami Ortodok & $\begin{array}{l}\text { Abu A'la } \\
\text { al Maududi }\end{array}$ & $\begin{array}{l}\text { Mendirikan khilafah hukumnya wajib } \\
\text { Kedaulatan hanya milik Allah } \\
\text { Negara harus berdasarkan pada al Quran } \\
\text { dan Sunnah }\end{array}$ \\
\hline 2. & \multirow{2}{*}{ Islami Modern } & $\begin{array}{l}\text { Jamaluddin al } \\
\text { Afgani }\end{array}$ & $\begin{array}{l}\text { Mendirikan khilafah tidak wajib } \\
\text { Kedaulatan di tangan Rakyat (Syura) } \\
\text { Boleh mengambil sesuatu yang baik } \\
\text { dari Barat }\end{array}$ \\
\cline { 4 - 5 } Abduh mad & $\begin{array}{l}\text { Mendirikan khilafah tidak wajib } \\
\text { Kedaulatan di tangan rakyat }\end{array}$ \\
\cline { 3 - 4 } 4. & $\begin{array}{l}\text { Yusuf } \\
\text { al Qardlawi }\end{array}$ & $\begin{array}{l}\text { Mendirikan khilafah hukumnya wajib } \\
\text { Dasar negara al Quran dan Sunnah } \\
\text { Menerima demokrasi (ala Islam/ } \\
\text { syura) }\end{array}$ \\
\hline
\end{tabular}




\begin{tabular}{|c|c|c|c|}
\hline 5. & \multirow{4}{*}{ Islam Sekular } & $\begin{array}{l}\text { Ali Abdu } \\
\text { al Raziq }\end{array}$ & $\begin{array}{l}\text { Mendirikan Khilafah hukumnya tidak } \\
\text { wajib } \\
\text { Kedaulatan berada di tangan kepala } \\
\text { Negara } \\
\text { Wajib taat pada seorang khalifah } \\
\text { Muhammad bertugas menyampaikan } \\
\text { risalah saja }\end{array}$ \\
\hline 6. & & $\begin{array}{l}\text { Abid } \\
\text { al Jabiri }\end{array}$ & $\begin{array}{l}\text { Mendirikan Khilafah tidak wajib } \\
\text { Fitnah al kubra disebabkan kekosongan } \\
\text { perundang-undangan dalam pemerintah- } \\
\text { an nabi Muhammad SAW. }\end{array}$ \\
\hline 7. & & $\begin{array}{l}\text { Muhammad } \\
\text { H u s a n } \\
\text { Haikal }\end{array}$ & $\begin{array}{l}\text { Umat Islam bebas menganut sistem } \\
\text { pemerintahan apapun } \\
\text { Pengambilan keputusan harus berdasar } \\
\text { musyawarah }\end{array}$ \\
\hline 8. & & $\begin{array}{l}\text { Abdullah an } \\
\text { Na'im }\end{array}$ & $\begin{array}{l}\text { Syariah dapat dijalankan jika lepas dari } \\
\text { kekuasaan negara } \\
\text { Kedaulatan di tangan rakyat (public } \\
\text { reason) }\end{array}$ \\
\hline
\end{tabular}

\section{Simpulan}

Pemikir Islamis mendasarkan teori politiknya kepada; pertama, mendirikan negara merupakan kewajiban kifayah bagi umat Islam. Jika negara Islam tidak bisa berdiri maka berdosalah seluruh umat Islam. Kedua, bentuk negara harus berupa kekhalifahan, karena pada dasarnya Islam telah memberikan contoh konkrit bentuk negara yaitu negara Madinah. Ketiga, kedaulatan hanyalah mutlak milik Tuhan, walaupun ada sebagian dari mereka yang mengatakan bisa menerima demokrasi tetapi demokrasi tersebut secara subtansional tidak boleh keluar dari nilai-nilai syariah, atau dengan kata lain bahwa demokrasi harus sesuai dengan al Quran dan Sunnah. Keempat, mentaati khalifah hukumnya wajib sebagaimana mentaati seorang imam dalam shalat, bahkan mereka tidak membenarkan menentang khalifah walaupun khalifah itu menyeleweng.

Sedangkan pemikir sekular mempunyai pandangan lain yaitu; pertama,mendirikan negara merupakan kebutuhan yang bersifat rasional bukan kewajiban agama. Kedua, bentuk negara bisa berupa apa saja apakah konstitusional, atau kekuasaan mutlak, apakah republik atau diktator. Ketiga, kedaulatan adalah sepenuhnya milik rakyat, yaitu dari rakyat, oleh rakyat dan untuk rakyat. Keempat, kepala negara hanya mempertanggungjawabkan pekerjaannya di hadapan rakyat tidak di hadapan Tuhan. 
Perwujudan sistem politik Islam adalah sistem kekhilafahan yang keberadaannya dimulai sejak zaman Rasulullah SAW hijrah ke Madinah hingga runtuhnya khilafah di Turki. Sebagai ganti dari sistem khilafah adalah sistem pemerintahan nation state (negara bangsa) yang merupakan sistem pemerintahan demokrasi yang banyak digunakan oleh negara-negara Muslim dewasa ini.

\section{Daftar Pustaka}

Al Jabiri,Muhammad Abid. 2001.Agama, Negara dan Penerapan Syariah. Yogyakarta: Fajar Pustaka Baru.

Al Maududi,Abul A'la. 1995.Hukum dan Konstitusi Sistem Politik Islam. Diterjemahkan oleh: Drs. Asep Hikmat. Bandung: Mizan.

Al Qardawi,Yusuf. 1999.Min fiqh alDaulah fi allslam, Kairo: Dar alSyuruq.

AnNa'im, Abdullahi Ahmed. 2007.Islam dan Negara Sekular Menegosiasikan Masa Depan Syari'ah. Bandung: Mizan Media Utama.

As Salus, Ali. 1997.Imamah E Khilafah dalam Tinjauan Syar'i.Jakarta: Gema Insani Press.

Azra,Azyumardi. 1996.Pergolakan Politik Islam.Jakarta: Paramadina.

Black, Antony. 2001.Pemikiran Politik Islam dari Masa Nabi hingga Masa Kini. Jakarta: Serambi.

Engineer, Asghar Ali. 2000.Devolusi Negara Islam. Yogyakarta: Pustaka Pelajar.

Ibnu Syarif, Mujar dan Khamami, 2008. Figh Siyasah Doktrin dan Pemikiran Politik Islam.Jakarta: Pt. Gelora Aksara Pratama.

Pulungan, J. Suyuthi. 1999. Fiqh Siyasah Ajaran, Sejarah dan Pemikiran. Jakarta: PT. Raja Grafindo Persada.

Sjadzali, Munawir. 1993. Islam dan Tata Negara.Jakarta:UIPress.

http://zfikri.wordpress.com/2007/08/11/kritik-kpd-an-naim-shariah-yes-ham-no. diakses tgl 25-6-2010.

http://azizfahri.blogspot.com/2010/11/pemikiran-politik-Abul A'la al Maududi .htmldiakses tgl 3-6-2011. 